\title{
Board of Commissioners Involvement and Shareholder's Wealth
}

\author{
Zaitul, Elfiswandib, Desi Ilonab
}

\begin{abstract}
Using Continental European data on Indonesia, this research investigates the effect of Board of Commissioners involvement which is measured by responsibility, seniority, women participation and independency on shareholder's wealth. This paper is the first research that examines the association between Board of Commissioners involvement and shareholder's wealth based on 249 Indonesia listed companies. Panel data analysis was used to assess whether the Board of Commissioners responsibility and independency have positive effect on shareholder's wealth. Based on the finding, seniority and women involvement have a negative relationship with shareholder's wealth. These findings have practical implication, i.e. the shareholders should consider the Board of Commissioners involvement in appointing and dismissing them. Theoretically, these findings contributed to the agency theory in the way that the Board of Commissioners involvement could reduce the agency cost and increase the wealth of shareholders.
\end{abstract}

Index Terms: Board of Commissioners Involvement: shareholder's wealth

\section{INTRODUCTION}

In the last decade, the power of the principal as an owner has moved to the board significantly. It creates agency problem between shareholders and board with regards to control of company's operation. To reduce this problem, a good corporate governance system is needed to enhance the wealth of shareholders which vary depending on the implementation of good corporate governance. Corporate governance refers to a set of policies that emphasize on how to build relationship among Board of Commissioners, Board of Directors, shareholders and other stakeholders (Chiang \& Lin, 2007). In fact, La Porta, Lopez-de-Silanes, Shleifer and Vishny (2000) define corporate governance as a set of official mechanisms to safeguard the interest of outside stockholders from the firm insiders.

The board has a critical role in maintaining corporate governance soundness (Ooi, Hooy, \& Som, 2017), particularly in crucial activities that can determine a company's failure or success (Byrd, Martin, \& Rath, 2010). Most of prior articles that investigate the effect of board on shareholders focus on the developed nations such as the United Kingdom and America (Bohdanowicz, 2015; and

Revised Manuscript Received on September 22, 2019

Zaitul, Economics Faculty, Universitas Bung Hatta, Padang 25133, Indonesia.

Elfiswandib, Economics Faculty, Universitas Putra Indonesia YPTK, Padang 25221, Indonesia.

Desi Ilonab, Economics Faculty, Universitas Putra Indonesia YPTK, Padang 25221, Indonesia, desiilona@upiyptk.ac.id
Muller-Kahle, Wang, \& Wu, 2014). Specifically, the studies focus on the countries such as U.S. (Baysinger \& Hoskisson, 1989; Carter, D’Souza, Simkins, \& Simpson, 2010), Malaysia (Ameer, Ramli, \& Zakaria, 2010), New Zealand (Boyle \& Ji, 2013), and India (Ghosh, 2018). In addition, prior studies in Continental European's scope concentrates on Board of Commissioners size and diversity (Bohdanowicz, 2015), Women on Board (Zaitul \& Ilona, 2018), ownership concentration (Darmadi, 2016), and ownership structure (Arosa, Iturralde, \& Maseda, 2010). Indonesia adapts Continental European system which has two separated boards, i.e. Board of Commissioners and Board of Directors. The main task of Board of Commissioners is to monitor the Board of Director's action. The Board of Directors manages the company's operation. The present study only focuses on the Board of Commissioners.

The degree of the Board of Commissioners involvement in company's strategy is dependent on their abilities and knowledge. An inefficient board involvement is a primary factor that adversely affect capital market interest and investor trust (Wijethilake, Ekanayake, \& Perera, 2015). In addition, Muhammad, Wasiuzzaman and Salleh (2016) argue that the boards involvement in strategic decision-making is insufficient and they only act as board council. The involvement of Board of Commissioners in a company is to monitor the action taken by Board of Directors. To date, only Wijethilake et al. (2015) investigated board involvement in corporate performance for countries that adapts the Anglo-Saxon system. They measure board involvement by using board shareholding, board meeting, board size, CEO duality and CEO as promotor. However, there are insufficient studies that examine the effect of Board of Commissioners involvement as measured by responsibility, seniority, women involvement and Board of Commissioners independence in a country which follows Continental European system such as Indonesian. The article is structured based on five sections. Section two discusses the literature review of this paper. Section three deals with a brief methodological approach. The next section explains the results and discussion of the findings. The final section addresses the conclusion and recomendation of the current study. 


\section{LITERATURE REVIEW}

\section{A. Shareholders Wealth}

There are many studies that investigated shareholder's wealth in different area, i.e. Sukuk and conventional bonds (Sherif \& Erkol, 2017), board attributes (Redor, 2016), dividend (Nguyen, 2014), CEO turnover (Ting, 2013), and corporate real estate (Liow \& Ooi, 2006). However, there is a lack of studies that investigate the effect of Board of Commissioners involvement on shareholder's wealth. Corporate governance system requires that Board of Commissioners to create the shareholder's wealth (Yahanpath \& Joseph, 2011). Firm tries to achieve its objective of shareholder's wealth maximization by investing, financing and dividend decision. According to Misra and Vishnani (2012) shareholders believe that the managers will invest the funds available in order to maximize their wealth through projects that can improve company size and provide adequate returns to them.

Possible conflict or agency problems between shareholders and management arises from the divergence of corporate ownership and control (Dockery, Herbert, \& Taylor, 2000). Jensen and Meckling (1976) argue that maximation of shareholder's wealth is not always compatible with firm's social obligation. In addition, it usually involves an agency problem which arises when the managers fail to act in the best interest of the shareholders, preferring instead to benefit themselves. This condition would create the agency cost and affect the shareholder's wealth. According to Ntow-gyamfi, Bokpin and Gemegah (2015), agency cost such as budgeting, control, auditing and compensation system is expenditure incurred which arise due to separation of ownership and control of companies. This costs are used in order to align the principal and agent interest through reducing agents' parochial interest. Thus, it increases the agency costs will impact on reducing the shareholder's wealth.

\section{B. Board of Commissioners}

Indonesia adapts two-tier board system, that is Board of Directors (manager) and Board of Commissioners (supervisor of manager). It means that there is a separation function of board as control and monitoring in a company. This paper focus to discuss Board of Commissioners. Until today, the prior findings that examine the effect of Board of Commissioners involvement on shareholder's wealth are limited. Prior paper in Continental European country such as Bohdanowicz (2015) who investigates the effect of ownership structure on size and Board of Commissioners diversity for 382 Polish companies in period 2004-2012. Bohdanowicz (2015) founds ownership structure has a positive impact on size and Board of Commissioners diversity. Study in Indonesia, Darmadi (2013) concentrate on women in top management team. He find that the presence women in top management team has a negative association with ROA and Tobin's q.

\section{Board of Commissioners Responsibility}

The responsibility of the Board of Commissioners refers to a board which has a strong responsibility to company where Board was firstly assigned. They do not involve in others companies as Board of commissioners and Board of Directors. Some previous studies use other terms to explain board responsibility such as multiple directorships (Kiel \& Nicholson, 2006; Sarkar \& Sarkar, 2009) and busy board (Jackling \& Johl, 2009; Lu, Wang, \& Dong, 2013). A Board of Commissioners with less responsibility has a positive and negative impact on shareholder's wealth. Khorana, Tufano and Wedge (2007) noted that the experience of Board of Commissioners will increase if a board member is also a board member in other companies. It increases the ability of Board Commissioners to monitor the Board of Director's action. However, Fich and Shivdasani (2006) argued that of a Board with less responsibilities provides weak of corporate governance resulting in poor performance of the board. In addition, Field, Lowry, and Mkrtchyan (2013) believe that board members are also appointed in other companies, they can create better experience and contact that can improve their advisors but ineffective in monitor onfirstly assigned company. It can be concluded that strong responsibility of Board of Commissioners will increase the shareholder's wealth. Based on the theory and previous researches, we propose the following hypothesis:

H1: Responsibility of Board of Commissioners has a positive relationhsip with shareholder's wealth

\section{Board of Commissioners Seniority}

Board of Commissioners seniority refers to the length of duration board as Board of Commissioners members in a company. Prior studies use other term to equate board seniority is tenure by Walters, Kroll, and Wright (2007), Hamzah and Zulkafli (2014), Hu, Hao, Liu, and Yao (2015), and Tarus \& Ayabei (2016). According to Hamzah \& Zulkafli (2014), Board of Commissioners seniority create more experience and maturity that influence decision making. Tarus and Ayabei (2016) believe that length seniority of board members in a company will improve monitoring of the management's action. Thus, longer seniority board provides more experience, information and ease to monitor the Board of Directors' action. While, Mcclelland, Barker, and Oh (2012) state that younger board is more flexible for environmental change and organization options than board seniority. Most existing studies on board seniority focus on CEO in One-Tier board system ( Mcclelland et al.,2012; \& Hu et al.,2015). In addition Byrd et al. (2010) claim that very few research which investigate director seniority or tenure. Furthermore, there is a lack study that investigates Board of Commissioners seniority and shareholder's wealth in a Two-Tier board system. Prior studies indicate that CEO seniority produces lower future accounting performance (Mcclelland et al., 2012) and reduces company leverage (Tarus \& Ayabei, 2016). On the contrary, Byrd et al. (2010) find director seniority has insignificant association with CEO compensation. The following hypothesis is proposed accordingly: 
H2: Board of Commissioners seniority has a positive relationship with shareholder's wealth

\section{E. Women on Board of Commissioners}

The presence women on board increases financial performance and better corporate governance practice (Willows \& Linde, 2016). According to Abad, Lucas-pérez, Minguez-vera, and Yagüe (2017), the presence women on board will produce full information to stakeholders and reduce information asymmetry in the market participants. Women is more discipline and honest than man. Adding women on Board of Commissioners can monitor the Board of Directors' action in reducing information asymmetry. The presence women on board has been investigated by many scholars which is related with various scopes such as firm risk (Lenard, Yu, York, \& Wu, 2014), information asymmetry (Abad et al., 2017), management system (Ali \& Konrad, 2017), corporate social responsibility (Muttakin, Khan, \& Subramaniam, 2015), human and social capital (Ooi et al., 2017), firm performance (Darmadi, 2013), and gender policies (Thams, Bendell, \& Terjesen, 2018). However, there is limited study that explore gender on Board of Commissioners and shareholder's wealth. Terjesen, Sealy, and Singh (2009) state that women on board contributes a knowledge, unique skills, and experience to their task. Study in Spain, Abad et al. (2017) find the presence women on board has a negative impact on information asymmetry. For 117 samples are selected by using the stratified random sampling, Ibrahim and Hanefah (2016) find that adding women on board has a significant and positive relationship with CSR. Campbell and Mínguez-Vera (2008) conclude that women directors have a positive impact on company value, which is shareholder's value. However, Farrell and Hersch (2005) claims that Board with more women does not destroy company value. As such, the following hypothesis is proposed:

H3: Women on Board of Commissioners has a positive effect on shareholder's wealth

\section{F. Board of Commissioners Independence}

Actually, Indonesia's corporate governance system has separated between board as monitoring (Board of Commissioners) and board as manager (Board of Directors). One of the Board of Commissioners members are independence. Beasley (1996) defines independent director as outside director who no association with dominant shareholders. According to Rashid (2018), the contention of board independence arises from the one tier board system. Some prior finding believe that Board of Commissioners independence is related to superior shareholder's wealth (Baysinger \& Butler, 1985; Rashid, 2018). Muhammad et al. (2016) find board independence has no association with earning management for post-RMCCG (2007) and full sample but positive impact on pre-RMCCG (2007). Helland and Sykuta (2005) conclude that board with higher proportions of outside directors perform a better job in monitoring management. Better monitoring will minimalize the agency cost and finally increase the performance of company and the wealth of shareholders. The following hypothesis is developed.

H4: Board of Commissioners independence has a positive effect on shareholder's wealth

\section{METHODS}

This study uses the 249 Indonesian listed companies from 2014 to 2016. Secondary data is gathered from company annual report, performance summary reports and other relevant company report that are taken from Indonesia's stock exchange website, company website and other electronic sources. There are two variables used in this study: dependent and independent variables. Most of prior papers investigate the shareholders wealth using market performance such as share price (Cotter, Shivdasani, \& Zenner, 1997), economic value added (EVA) and market value added (MVA) (Liow \& Ooi, 2006), and share price reaction (Huang \& Chen, 2012). However, shareholder's wealth variable of the current paper is measured by Return on Asset (ROA) which represents the capability of agent to use company's assets more efficient, which contributes to shareholder's wealth (Carpenter, Sanders, \& Gregersen, 2001) and it is as effective measure (Core, Holthausen, \& Larcker, 1999). Board of Commissioners responsibility is proxy by Board of Commissioners are also as board member in other companies (Jackling \& Johl, 2009). In addition, Board of Commissioners seniority is defined as how long the board members served (Hamzah \& Zulkafli, 2014). Further, women on Board of Commissioners is measured based on percentage of women on board (Thams et al., 2018). Finally, Board of Commissioners independence is measured by percentage of Board of Commissioners from outside (Rashid, 2018).

\section{A. Data Collection}

This study uses secondary data from the annual report, financial report and performance report. These reports are gathered from the Indonesia Stock Exchange website (www.idx.co.id), company website and other electronic sources.

\section{B. Data Analysis}

Multiple regression analysis using panel approach is applied in this study. Classical assumptions, such as normality, multicollinearity and heteroscedasticity. Normality test using the Kolmogorov-Smirnov (KS). In this case, the variable is not normal, it would be transformed into Ln or Square root. Skewness divided by standard errors (Manning \& Munro, 2004) used if using KS is still not normal. Multicollinearity problem is detected by using the person correlation and VIF. Heteroscedasticity problem detected by using white test (White, 1980). if there is a heteroscedastic problem, it can be solved by applying White Heteroscedasticity Consistent Variance (Wooldridge, 2003). 


\section{RESULTS AND DISCUSSION}

There are 249 companies from diverse sector which involved in this study as final sample. Statistic descriptive of the research variables are demonstrated in Table 1. Shareholder's wealth has a means value of $2.57 \%$. in addition, the maximum and minimum value are $40.18 \%$ and $-54.83 \%$ respectively. Means value of Board of commissioner's responsibility is $40.09 \%$ which indicate that almost $50 \%$ of board members has another position in other companies as Board of Commissioners or as Board of Directors. Further, Board of Commissioners seniority which measured by the length of board member as Board of Commissioners in a company. Maximum value of Board of Commissioners seniority is 30.67 years with means value of 6.017 years. Thus, the means value for women on Board of Commissioners is $14.90 \%$. The maximum and minimum value is $67 \%$ and $0 \%$. Finally, Board of Commissioners independence has average value of $39.760 \%$ and maximum value of $80 \%$.

Table 1.Statistic Descriptive of Variables

\begin{tabular}{c|c|c|c|c|c}
\hline No. & Variables & Min & Max & Means & SD \\
\hline 1 & SW & -54.83 & 40.18 & 2.57 & 9.58 \\
\hline 2 & BCR & 0.00 & 1.00 & 40.09 & 33.28 \\
\hline 3 & BCS & 0.00 & 30.67 & 6.02 & 4.78 \\
\hline 4 & WBC & 0.00 & 67.00 & 14.90 & 18.53 \\
\hline 5 & BCI & 0.00 & 80.00 & 39.76 & 11.71 \\
\hline
\end{tabular}

Notes: Shareholder's Wealth (SW), Board of Commissioners Responsibility (BCR), Board of commissioners Seniority (BCS), Women on Board of commissioners (WBC), and Board of Commissioners Independence $(\mathrm{BCI}$

To have a best, linear, unbiased and estimator from a regression model, it must be free from classical assumptions: normality, multicollinearity and heteroscedasticity. Normality is identified by using the Kolmogorov-Smirnov test based on the cut off value of 0.05. As shown in Table 1, all variables are not normal. As such, shareholder's wealth and Board of commissioner's seniority are transformed into square root (sqrt) and retested their normality using the KS test. The result show that these variables are normal. Board of Commissioners responsibility and independence are normal by using the skewness/errors with values are below 2.59 (Manning and Munro, 2004). However, women on Board of Commissioners was transformed into $\mathrm{Ln}$ and retested using skewness/errors. Thus, the result show that the variable is finally normal.

Table 2 Test of Normality and Transformation

\begin{tabular}{l|l|l|l|l|l|l|l}
\hline $\begin{array}{l}\text { N } \\
\text { o }\end{array}$ & $\begin{array}{l}\text { Variab } \\
\text { les }\end{array}$ & $\begin{array}{l}\text { KS } \\
\text { Asym } \\
\text { Sig. }\end{array}$ & $\begin{array}{l}\text { Cu } \\
\text { t } \\
\text { Off }\end{array}$ & $\begin{array}{l}\text { Conclus } \\
\text { ion }\end{array}$ & $\begin{array}{l}\text { Tran } \\
\text { s. }\end{array}$ & $\begin{array}{l}\text { Skew/S } \\
\text { E }\end{array}$ & $\begin{array}{l}\text { Conclusio } \\
\text { n }\end{array}$ \\
\hline 1 & SW & 0.00 & $\begin{array}{c}0.0 \\
5\end{array}$ & $\begin{array}{c}\text { Not } \\
\text { normal }\end{array}$ & $\begin{array}{c}\mathbf{0 . 2 0} \\
*\end{array}$ & & Normal \\
\hline 2 & BCR & $\mathbf{0 . 0 0}$ & $\begin{array}{c}0.0 \\
\text { Not } \\
\text { normal }\end{array}$ & & $2.96 * *$ & Normal \\
\hline
\end{tabular}

\begin{tabular}{c|l|c|c|c|c|c|c}
\hline 3 & BCS & $\mathbf{0 . 0 0}$ & $\begin{array}{c}0.0 \\
5\end{array}$ & $\begin{array}{c}\text { Not } \\
\text { normal }\end{array}$ & $\begin{array}{c}0.15 \\
*\end{array}$ & & Normal \\
\hline 4 & WBC & $\mathbf{0 . 0 3}$ & $\mathbf{0 . 0}$ & Not & & $\mathbf{0 . 3 4} * *$ & Normal \\
& & 5 & normal & & $*$ & \\
\hline 5 & BCI & $\mathbf{0 . 0 0}$ & $\mathbf{0 . 0}$ & Not & & $-\mathbf{0 . 0 1 1} *$ & Normal \\
& & & 5 & normal & & $*$ & \\
\hline
\end{tabular}

Notes: * normal distributed after transforming into sqrt, ** and *** normal distributed using skewness/error. Shareholder's Wealth (SW), Board of Commissioners Responsibility (BCR), Board of commissioners Seniority (BCS), Women on Board of commissioners (WBC), and Board of Commissioners Independence (BCI)

The next classical assumption is multicollinearity problem. this problem occurs when there is relationship among independent variables. there are several test to identified whether any problem of multicollinearity in the model, such as pearson correlation test and VIF. In this study, these two tests are used to identify the multicollinearity problem. the result of Pearson correlation test could be seen in Table 3. The correlation coefficient between independent variables are below 0.70 and it can conclude that there is no problem of multicollinearity. This conclusion is also supported by value of VIF for all independent variables (shown in Table 4) which are below 10.

Table 3 Multicollinearity Test

\begin{tabular}{cccccc} 
No. & $\begin{array}{c}\text { Variable } \\
\text { s }\end{array}$ & BCR & BCI & WBC & BCS \\
\hline 1 & BCR & 1 & & & \\
2 & BCI & -0.012 & 1 & & \\
3 & WBC & -0.066 & 0.035 & 1 & \\
4 & BCS & $\mathbf{0 . 0 7 4 * *}$ & $-\mathbf{0 . 0 5 7}$ & $\mathbf{0 . 0 0 0}$ & 1 \\
\hline
\end{tabular}

Notes: Board of Commissioners Responsibility (BCR), Board of commissioners Seniority (BCS), Women on Board of commissioners (WBC), and Board of Commissioners Independence (BCI)

The last classical assumption is heteroscedastic problem. this problem is identified using White test (white, 1980). The result show that there is a such problem in the model. In this study, this problem is solved by using the heteroscedasticity corrected model which is available in many statistic software, such as GRETL. The result of heteroscedasticity corrected model is demonstrated in Table 4. The research model is very much fit or feasible. It can be shown by $\mathrm{F}$ significant are far below the cut off (0.05). in addition, $\mathrm{R}$ square is $20.605 \%$ which means that dependent variable could be explained by $20.605 \%$ of independent variables and the rest are not excluded in this model.

The regression result show that two hypotheses are accepted (BCR and BCI) and another two are rejected (BCS and WBC). The effect of Board of Commissioners responsibility on shareholder's wealth are significantly positive ( $\mathrm{p}$ value of BCR is less than 0.05). Another word, the higher of responsibility of

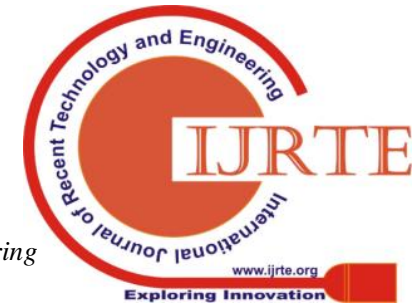


Board of Commissioners increase shareholder's wealth. However, the Board of Commissioners seniority has a negative relationship with the shareholder's wealth. This finding is supported prior work of (Mcclelland et al., 2012). They find CEO seniority will be lowering future financial performance. It means that longer Board of Commissioners sitting as board members destroy the wealth of shareholders. In line with Board of Commissioners seniority, women on Board of Commissioners also have a negative significant relationship with shareholder's wealth. Woman on board does not bring toa positive value to the wealth of shareholders. This result is opposite with prior research of Abad et al. (2017). They found adding women on board is lowering the quality of information. Contrast to the women and seniority, Board of Commissioners independence positively influence the shareholder's wealth. More independent member of Board of Commissioners improve the wealth of shareholder.

Table 4 Regression Results

\begin{tabular}{|c|c|c|c|c|c|c|}
\hline No. & Variables & Coef & t stat & $\begin{array}{c}P \\
\text { value }\end{array}$ & VIF & Conclusion \\
\hline 1 & Constant & 1.031 & 3.712 & 0.000 & & \\
\hline 2 & BCR & 0.660 & 3.636 & 0.000 & 1.022 & Accepted \\
\hline 3 & BCS & -0.221 & -3.771 & 0.000 & 1.015 & Rejected \\
\hline 4 & WBC & -0.522 & -4.908 & 0.000 & 1.005 & Rejected \\
\hline \multirow[t]{4}{*}{5} & BCI & 2.081 & 4.908 & 0.000 & 1.004 & Accepted \\
\hline & F stat & & & 17.324 & & \\
\hline & F sig & & & 0.000 & & \\
\hline & R square & & & 20.605 & & \\
\hline
\end{tabular}

Notes: Shareholder's wealth is dependent variable, and independent variables: Board of Commissioners Responsibility (BCR), Board of commissioners Seniority (BCS), Women on Board of commissioners (WBC), and Board of Commissioners Independence (BCI)

\section{CONCLUSION AND RECOMMENDATION}

To the best of our investigation, there is no prior research that examines the effect of Board of Commissioners involvement on shareholder's wealth. Board of Commissioners responsibility and independency have a positive relationship with the shareholder's wealth. However, Board of Commissioners seniority and women on Board of Commissioners have a negative effect on the shareholder's wealth. These findings could be considered for company's policy maker and other stakeholders to make the relevance decision. In addition, this study has gone some way towards enhancing our understanding of corporate governance in a unique Continental European system, such as Indonesia. Finally, a number of important limitations need to be considered. First, this study only focused on the Board of Commissioners rather than Board of Directors or other corporate governance internal mechanisms. Second, this research emphasizes on companies listed in all sectors. Finally, this study uses the panel data analysis to achieve the research's object. Further research might investigate the role of Board of directors on shareholder's wealth. in addition, future research also could assess from specific industries or sector.

\section{CONFLICT OF INTEREST}

There is no conflict of interest.

\section{ACKNOWLEDGMENTS}

We thank Prof. Amran Rasli for constructive comment on manuscript of this paper. We also thank for Dr. Goh Cin Fei for supporting data analysis knowledge's during workshop. Our gratitude also to Rector of Universitas Bung Hatta and Universitas Putra Indonesia YPTK Padang.

\section{REFERENCES}

[1] Abad, D., Lucas-pérez, M. E., Minguez-vera, A., \& Yagüe, J. (2017) Does gender diversity on corporate boards reduce information asymmetry in equity markets? Bussiness Research Quarterly, 20, 192-205. https://doi.org/10.1016/j.brq.2017.04.001

[2] Ali, M., \& Konrad, A. M. (2017). Antecedents and consequences of diversity and equality management systems : The importance of gender diversity in the TMT and lower to middle management. European $\begin{array}{lll}\text { Management } & \text { Journal, } & \text { 35(4), }\end{array}$ https://doi.org/10.1016/j.emj.2017.02.002

[3] Ameer, R., Ramli, F., \& Zakaria, H. (2010). A new perspective on board composition and firm performance in an emerging market. Corporate Governance: The International Journal of Business in Society, 10(5), 647-661. https://doi.org/10.1108/14720701011085607

[4] Arosa, B., Iturralde, T., \& Maseda, A. (2010). Ownership structure and firm performance in non-listed firms: Evidence from Spain. Journal of Family Business $\quad$ Strategy, $1(2), \quad 88-96$. https://doi.org/10.1016/j.jfbs.2010.03.001

[5] Baysinger, B. D., \& Butler, H. N. (1985). Corporate Governance and the Board of Directors: Performance Effects of Changes in Board Composition Corporate Governance and the Board of Directors: Performance Effects of Changes in Board Composition. Journal of Law, Economics, \& Organization, 1(1), 101-124.

[6] Baysinger, B., \& Robert E. Hoskisson. E. (1989). Diversification strategy and $\mathrm{R} \& \mathrm{D}$ intensity in multiproduct firms. Academy of Management Journal, 32(2), 310-332. https://doi.org/10.2307/256364

[7] Beasley, M. S. (1996). An empiral analysis of the relationship between the board of director composition and financial statement fraud. The Accounting Review, 71(4), 443-465.

[8] Bohdanowicz, L. (2015). The Impact of Ownership Structure on Supervisory Board Size and Diversity: Evidence from the Polish Two-tier Board Model. Procedia Economics and Finance, 23, 1420-1425. https://doi.org/10.1016/S2212-5671(15)00429-3

[9] Boyle, G., \& Ji, X. (2013). New Zealand corporate boards in transition: Composition, activity and incentives between 1995 and 2010. Pacific Accounting Review, 25(3), 235-258.

[10] Byrd, J., Martin, L. A., \& Rath, S. (2010). The shareholder wealth effects of an executive joining another company' $\mathrm{s}$ Board. International Journal of Managerial Finance, 6(1), 48-57. https://doi.org/10.1108/17439131011015788

[11] Campbell, K., \& Mínguez-Vera, A. (2008). Gender diversity in the boardroom and firm financial performance. Journal of Business Ethics, 83(3), 435-451. https://doi.org/10.1007/s10551-007-9630-y

[12] Carpenter, M. A., Sanders, W. M. G., \& Gregersen, H. A. L. B. (2001). Bundling Human Capital with Organizational Context: The Impact of International Assignment Experience on Multinational Firm Performance and CEO Pay. Academy of Management Journal, 44(3), 493-511. https://doi.org/10.2307/3069366

[13] Carter, D. A., D’Souza, F., Simkins, B. J., \& Simpson, W. G. (2010). The gender and ethnic diversity of US boards and board committees and firm financial performance. Corporate Governance, 18(5), 396-414. https://doi.org/10.1111/j.1467-8683.2010.00809.x

[14] Chiang, M.-H., \& Lin, J.-H. (2007). The Relationship between Corporate Governance and Firm Productivity: evidence from Taiwan's manufacturing firms. Corporate Governance: An International Review, 15(5), 768-779. 
https://doi.org/10.1111/j.1467-8683.2007.00605.x

[15] Core, J. E., Holthausen, R. W., \& Larcker, D. F. (1999). Corporate governance, chief executive officer compensation, and firm performance. Journal of Financial Economics, 51, 371-406. https://doi.org/10.1016/S0304-405X(98)00058-0

[16] Cotter, J. F., Shivdasani, A., \& Zenner, M. (1997). Do independent directors enhance target shareholder wealth during tender offers? Journal of Financial Economics, 43(2), 195-218. https://doi.org/10.1016/S0304-405X(96)00886-0

[17] Darmadi, S. (2013). Do women in top management affect firm performance? Evidence from Indonesia. Corporate Governance: The International Journal of Business in Society, 13(3), 288-304. https://doi.org/10.1108/CG-12-2010-0096

[18] Darmadi, S. (2016). Ownership concentration, family control, and auditor choice: Evidence from an emerging market. Asian Review of Accounting, 24(1), 19-42.

[19] Dockery, E., Herbert, W. E., \& Taylor, K. (2000). Corporate Governance, Managerial Strategies and Shareholder Wealth Maximisation: A Study of Large European Companies. Managerial Finance, 26(9), 21-35.

[20] Farrell, K. A., \& Hersch, P. L. (2005). Additions to corporate boards: The effect of gender. Journal of Corporate Finance, 11(1-2), 85-106. https://doi.org/10.1016/j.jcorpfin.2003.12.001

[21] Fich, E. M., \& Shivdasani, A. (2006). Are Busy Boards Effective Monitors? The Journal of Finance, 61(2), 689-724. https://doi.org/10.1111/j.1540-6261.2006.00852.x

[22] Field, L., Lowry, M., \& Mkrtchyan, A. (2013). Are busy boards detrimental? Journal of Financial Economics, 109(1), 63-82. https://doi.org/10.1016/j.jfineco.2013.02.004

[23] Ghosh, S. (2018). Banker directors and firm performance: Are family firms different? Future Business Journal, 4(1), 1-15. https://doi.org/10.1016/j.fbj.2017.11.002

[24] Hamzah, A. H., \& Zulkafli, A. H. (2014). Board diversity and corporate expropriation. Procedia - Social and Behavioral Sciences, 164(August), 562-568. https://doi.org/10.1016/j.sbspro.2014.11.146

[25] Helland, E., \& Sykuta, M. (2005). Who's monitoring the monitor? Do outside directors protect shareholders' interests? The Financial Review, 40(2), 155-172. https://doi.org/10.1111/j.1540-6288.2005.00098.x

[26] Hu, N., Hao, Q., Liu, L., \& Yao, L. J. (2015). Managerial tenure and earnings management. International Journal of Accounting \& Information Management, 23(1), 42-59. https://doi.org/10.1108/IJAIM-04-2014-0025

[27] Huang, W., \& Chen, K. C. (2012). Asset sales, asset exchanges, and shareholder wealth in China. Journal of Advanced Research, 2(1), 1-8. https://doi.org/10.1016/j.rdf.2012.01.002

[28] Ibrahim, A. H., \& Hanefah, M. M. (2016). Board diversity and corporate social responsibility in Jordan. Journal of Financial Reporting and Accounting, 14(2), https://doi.org/10.1108/MBE-09-2016-0047

[29] Jackling, B., \& Johl, S. (2009). Board structure and firm performance: Evidence from India's top companies. Corporate Governance, 17(4), 492-509. https://doi.org/10.1111/j.1467-8683.2009.00760.x

[30] Jensen, M., \& Meckling, W. (1976). Theory of the firm: managerial behavior, agency costs, and ownership structure. Journal of Financial Economics, $3(4)$,

$305-360$ https://doi.org/10.1017/CBO9780511817410.023

[31] Khorana, A., Tufano, P., \& Wedge, L. (2007). Board structure, mergers, and shareholder wealth: A study of the mutual fund industry. Journal of Financial Economics, 85(2), 571-598. https://doi.org/10.1016/j.jfineco.2006.05.002

[32] Kiel, G. C., \& Nicholson, G. J. (2006). Multiple directorship and corporate performance in Australian listed companies. An International Review, 14(6), 530-546. https://doi.org/DOI 10.1111/j.1467-8683.2006.00528.x

[33] La Porta, R., Lopez-de-Silanes, F., Shleifer, A., \& Vishny, R. (2000). Investor Protection and Corporate Governance. Journal of Financial Economics, 58 , $3-27$. https://doi.org/http://dx.doi.org/10.1016/S0304-405X(00)00065-9

[34] Lenard, M. J., Yu, B., York, E. A., \& Wu, S. (2014). Impact of board gender diversity on firm risk. Managerial Finance, 40(8), 787-803.

[35] Liow, K. H., \& Ooi, J. T. L. (2006). Does corporate real estate create wealth for shareholders? Journal of Property Investment \& Finance, 22(5), 386-400. https://doi.org/10.1108/14635780410556870

[36] Lu, X., Wang, J., \& Dong, D. (2013). Busy boards and corporate performance. China Finance Review International, 3(2), 203-219. https://doi.org/10.1108/20441391311330618

[37] Manning, M. L., \& Munro, D. (2004). The business survey researcher's SPSS cookbook. New South Wales.

[38] Mcclelland, P. L., Barker, V. L., \& Oh, W.-Y. (2012). CEO career horizon and tenure: Future performance implications under different contingencies. Journal of Business Research, 65, 1387-1393. https://doi.org/10.1016/j.jbusres.2011.09.003

[39] Misra, D., \& Vishnani, S. (2012). Impact of Corporate Governance Regulation on Market Risk. Vilkalpa, 37(2), 19-32. https://doi.org/10.1177/0256090920120203

[40] Muhammad, W. M. wan, Wasiuzzaman, S., \& Salleh, N. M. Z. (2016) Board and audit committee effectiveness, ethnic diversification and earnings management: a study of the Malaysian manufacturing sector. Corporate Governance, 16(4), 726-746. https://doi.org/10.1108/CG-06-2015-0085

[41] Muller-Kahle, M. I., Wang, L., \& Wu, J. (2014). Board structure: an empirical study of firms in Anglo-American governance environments. Managerial Finance, 40(7), 681-699. https://doi.org/10.1108/MBE-09-2016-0047

[42] Muttakin, M. B., Khan, A., \& Subramaniam, N. (2015). Firm characteristics, board diversity and corporate social responsibility: Evidence from Bangladesh. Pacific Accounting Review, 27(3), $353-372$.

[43] Nguyen, K. H. (2014). Impact of a dividend initiation wave on shareholder wealth. Applied Financial Economics, 24(8), 573-586.

[44] Ntow-gyamfi, M., Bokpin, G. A., \& Gemegah, A. (2015). Corporate governance and transparency : evidence from stock return synchronicity. Journal of Financial Economic Policy, 7(2), 157-179. https://doi.org/10.1108/JFEP-10-2013-0055

[45] Ooi, C., Hooy, C., \& Som, A. P. M. (2017). The influence of board diversity in human capital and social capital in crisis. Managerial Finance, 43(6), 700-719. https://doi.org/10.1108/MF-08-2016-0226

[46] Rashid, A. (2018). Board independence and firm performance: Evidence from Bangladesh. Future Business Journal, 4(1), 34-49. https://doi.org/10.1016/j.fbj.2017.11.003

[47] Redor, E. (2016). Board attributes and shareholder wealth in mergers and acquisitions : a survey of the literature. J Manag Gov, 20, 789-821. https://doi.org/10.1007/s10997-015-9328-y

[48] Sarkar, J., \& Sarkar, S. (2009). Multiple board appointments and firm performance in emerging economies: Evidence from India. Pacific Basin Finance Journal, 17(2), 271-293. https://doi.org/10.1016/j.pacfin.2008.02.002

[49] Sherif, M., \& Erkol, C. T. (2017). Sukuk and conventional bonds shareholder wealth perspective. Journal of Islamic Accounting and Business Research, 8(4), 347-374. https://doi.org/10.1108/JIABR-09-2016-0105

[50] Tarus, D. K., \& Ayabei, E. (2016). Board composition and capital structure: evidence from Kenya. Management Research Review, 39(9), 1056-1079. https://doi.org/10.1108/MRR-01-2015-0019

[51] Terjesen, S., Sealy, R., \& Singh, V. (2009). Women directors on corporate boards: A review and research agenda. Corporate Governance, $17(3)$, https://doi.org/10.1111/j.1467-8683.2009.00742.x

[52] Thams, Y., Bendell, B. L., \& Terjesen, S. (2018). Explaining women's presence on corporate boards: The institutionalization of progressive gender-related policies 败. Journal of Business Research, 86(may), 130-140. https://doi.org/10.1016/j.jbusres.2018.01.043

[53] Ting, H. (2013). CEO turnover and shareholder wealth : Evidence from CEO power in Taiwan 25 Journal of Business Research, 66(12), 2466-2472. https://doi.org/10.1016/j.jbusres.2013.05.036

[54] Walters, B. A., Kroll, M. J., \& Wright, P. (2007). CEO tenure, boards of directors, and acquisition performance. Journal of Business Res, 60, 331-338. https://doi.org/10.1016/j.jbusres.2006.12.001

[55] White, H. (1980). A heteroskedasticity-consistent covariance matrix estimator and a direct test for heteroskedasticity. Econometrica, 48(4), 817-838.

[56] Wijethilake, C., Ekanayake, A., \& Perera, S. (2015). Board involvement in corporate performance: evidence from a developing country. Journal of Accounting in Emerging Economies, 5(3), 250-268. https://doi.org/10.1108/JAEE-12-2012-0050

[57] Willows, G., \& Linde, M. van der. (2016). Women representation on boards: a South African perspective. Meditari Accountancy Research, 24(2), 211-225.

[58] Wooldridge, J. M. (2003). Introductory Econometrics: A Modern Approach (2nd Editio). Ohio: Thomson South Western. https://doi.org/10.1017/asb.2017.16

[59] Yahanpath, N., \& Joseph, T. (2011). A brief review of the role of shareholder wealth maximisation and other factors contributing to the global financial crisis. Qualitative Research in Financial Markets, 3(1), 64-77. https://doi.org/10.1108/17554171111124621

Published By:

Blue Eyes Intelligence Engineering \& Sciences Publication

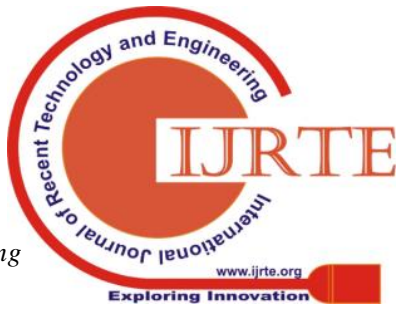


[60] Zaitul, \& Ilona, D. (2018). Gender in Audit Committee and Financial Reporting Timeliness : the Case of Unique Continental European Model. International Journal of Engineering \& Technology, 7(2.29), 436-442. https://doi.org/10.14419/ijet.v7i2.29.13668

\section{AUTHOR PROFILE}

I am Zaitul, affiliated with Economics Faculty, Universitas Bung Hatta, Padang 25133, Indonesia, my area of research is cooperate governance.

Elfiswandib, currently I am associated with Economics Faculty, Universitas Putra Indonesia YPTK, Padang 25221, Indonesia my area of research is cooperate governance.

Desi Ilonab, I am affiliated with Economics Faculty, Universitas Putra Indonesia YPTK, Padang 25221, Indonesia, my area of research is cooperate governance. 